\title{
Critical invasion science: weeds, pests, and aliens
}

\author{
Christian A. Kull, Univ. Lausanne
}

This is the authors' pre-print PDF version of the following book chapter:

Kull, Christian A. (2018) Critical invasion science: weeds, pests, and aliens. In The Palgrave Handbook of Critical Physical Geography, edited by Lave, R, C Biermann \& SN Lane. Cham, Switzerland: Palgrave Macmillan, pages 249272.

DOI: $10.1007 / 978-3-319-71461-5 \_12$.

The final, definitive version is published in the book mentioned above, available through the Springer website at this link, or via a DOI reference at http://dx.doi.org/10.1007/978-3-319-71461-5_12, or via your bookshop or library.

\begin{abstract}
The study of invasive plants and animals calls strongly for a critical approach due to the deeply social nature of invasion landscapes, the power relations affecting the science of invasions, and the differential impacts of weed or pest control on lives and landscapes. I first explore what a "critical" invasion science means. Then I investigate several aspects of invasion science ripe for critical analysis: the history of the science (to understand what the science is doing and why), the terminology and categories of analysis, and the highly contested social, political, and ethical context within which invasion management takes place. I conclude with four proposals for further work in critical invasion science and examples of the types of questions it might ask.
\end{abstract}

\section{Opening}

In July 2011, Nature magazine printed several irate responses to an article about the science of biological invasions by Mark Davis entitled "Don't judge species on their origins". The first response, led by the eminent scholar Daniel Simberloff, was titled threateningly "Non-natives: 141 scientists object". The spat has since widened. Science writers have published books with titles like "The New Wild: Why Invasive Species Will Be Nature's Salvation", "Where do Camels Belong? Why Invasive Species aren't all Bad”, and "Rambunctious Garden: Saving Nature in a Post-Wild World"; while invasion scientists have defended their field with journal articles such as "Misleading criticisms of invasion science: a field guide" and "The rise of invasive species denialism". ${ }^{1}$

What is going on here? The movements of plants and animals from one part of the world to another, their establishment and success in new environments, and their impacts on host communities would appear to be a fascinating, yet solidly scientific endeavor. A glance at the titles above, however, shows that the debate is more than scientific--it is about terminology, about values, about politics. It appears, then, that calls for a "Critical physical geography" (CPG) have emerged at the right time for studies of invasive species, whether in biogeography or elsewhere across the natural and social sciences.

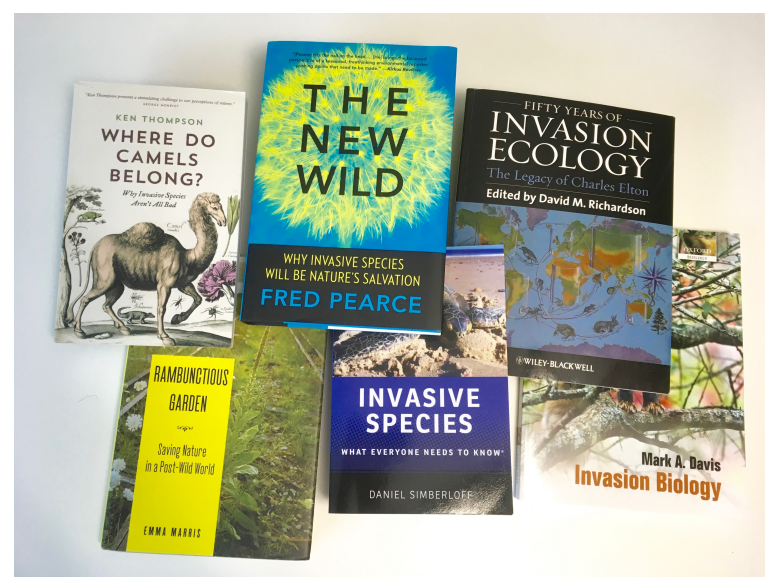

Figure 1. Books and authors mentioned in the text, illustrating some of the conflicting views of the science of invasions. 
According to the introductory chapter in this handbook, CPG has three core intellectual tenets: (1) that landscapes are not just biophysical but deeply shaped by human actions and structural inequalities; (2) that power relations affect who studies landscapes and how; and (3) that the resulting knowledge has deep impacts on lives and landscapes. These tenets are strongly applicable to the science of biological invasions. Let me illustrate with what might be one of the most striking examples: South Africa.

Tenet 1: Invasion landscapes deeply shaped by human actions and structural inequalities. Most problematic alien invasive species in South Africa were introduced in the colonial era, with goals related to utility (e.g., timber resources), land rehabilitation (e.g. dune stabilization), or science and aesthetics (e.g., botanic gardens and personal gardens). Colonization and Apartheid-era policies not only separated people, but also created starkly disjunctive landscapes whose legacies endure today (from peri-urban townships to rural 'homelands'; large properties for farming, forestry, and game ranching; suburban estates; conservation zones) and which form the matrix across which invasive species spread and are managed (van Wilgen et al. 2011, van Wilgen and Richardson 2012).

Tenet 2: Power relations affect who studies invasions, how, and the questions asked. South Africa has been a global leader in invasion biology, with strong historical roots in Cape Town-based circles of botanists, naturalists, and foresters (Pooley 2014). I may be sticking my foot in it to say this, but it is largely a "white" science--see for instance the core staff of the world-renowned Centre for Invasion Biology at Stellenbosch University. To be clear, this is not an accusation as I recognize the historical path dependency, the very engaged stances of many of these researchers, and the structural difficulties of attracting students from previously disadvantaged backgrounds to this field of study (but, this last element is perhaps precisely the point I am making). A generation has passed since the end of Apartheid, but according to some observers, "environmental engagement does not transcend but rather pronounces ecological and social inequities" (Carruthers et al. 2011, Bennett 2014, Green 2014, Lidström et al. 2015, p. 21). Significant research has been undertaken on the impacts of biological invasions for poorer, more marginal South Africans (e.g., Shackleton et al. 2007, Shackleton et al. 2015, Mukwada et al. 2016), yet problem framings until more recently largely started with the biological and hydrological impacts of invasions, not with the concerns of rural people.

Figure 2. Different views of invasives around South Africa: (top left) dense acacia brush in the foothills above Muizenberg and False Bay (Western Cape province); (top right) Acacia mearnsii shrub and woodlot near the Swazi border (Mpumalanga province); (bottom left) Acacia mearnsii used to build a cattle enclosure near Butterworth, former Transkei (Eastern Cape province); (bottom right) public works laborer controlling Lantana camara infestation (also near Butterworth).

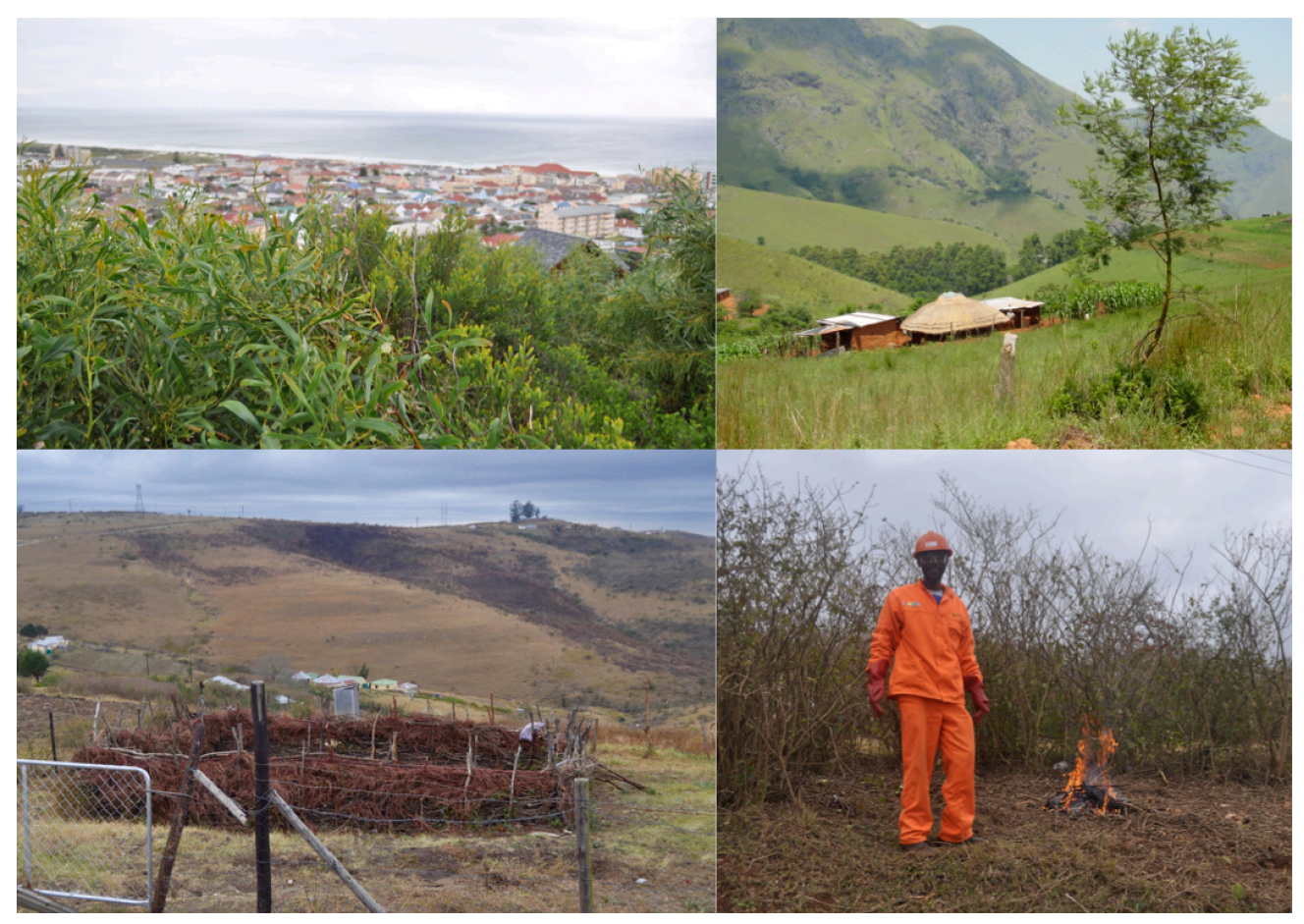


Tenet 3: Resulting knowledge has deep impacts on invasion landscapes and lives of people. The science produced on invasions in South Africa has numerous direct impacts. Biological control programs (releasing insects and pathogens to control invasions) date back to early $20^{\text {th }}$ Century struggles with prickly pear cactus (Beinart and Wotshela 2011) and continue today, sometimes dramatically shaping the ecology of invasive plant communities and leading to complaints by local users (Shackleton et al. 2007). The Working for Water program, a major postApartheid government program for job creation and ecological restoration paid and trained tens of thousands of poor black South Africans in mechanical and chemical control of invasive species (Turpie et al. 2008, Neely 2010, van Wilgen et al. 2011, Lidström et al. 2015). There is no doubt that the science has contributed to important impacts on many plants (uprooted), people (employed), resource-based livelihoods (disrupted), and landscapes (transformed).

In this chapter, I argue for the necessity of a critical approach to the study of invasive plants and animals. I first explore what a "critical" invasion science means. Then the bulk of the chapter investigates four main aspects of invasion science ripe for critical analysis: the history of the science, the terminology, the categories, and the social-political-ethical context. I conclude with four proposals for further work in critical invasion science and a review of the questions it might ask.

\section{The emergence of a critical approach}

First, however, I pass by a necessary detour. What is "critical physical geography", or why have I titled this chapter "critical invasion science"? Like many a good term, "critical" can mean different things in different contexts. As the Oxford English Dictionary notes, while "critical" may be defined most commonly as "given to judging, esp. given to adverse criticism", it has also meant "exercising careful judgment or observation" and has been specifically associated with the Frankfurt School of social theory and philosophy and its engagement with thinkers like Kant, Hegel, Marx, Weber, and Freud. This is the sense informing the use of the term in geography, where "critical" has gone on to signify scholarship informed by social theories, particularly with a sensibility to emancipatory forms of politics and also a "deconstructive impulse" with respect to scientific knowledge (Forsyth 2003, Gregory et al. 2009, p. 121)

"Critical" physical geography was proposed by Lave et al. (2014). The fact that this idea took hold reflects, in my opinion, three broader phenomena. The first is the commitment by practitioners to an integrative discipline, a rear-guard defense against trends of splitting human from physical geography. Such trends are deeply ironic given endless calls for more interdisciplinarity, especially at the boundaries of nature and society (cf Kull and Rangan 2016). In this sense, CPG emerges as a call for revitalizing some of the integration across physical and human that makes geography whole.

Second, political ecologists are relatively prominent among early enthusiasts for CPG. My intuition is that this enthusiasm by political ecologists for CPG is due to the fact that CPG lays claim to and gives visibility to territory that has been increasingly marginalized in political ecology. To put it bluntly: for people with a foot in both the natural sciences and critical social sciences, political ecology has been a productive home. Yet political ecology has over time more and more emphasized the social side over the natural science. So CPG gives an alternative home for people of a political ecological spirit with a real commitment to the natural sciences. As such, CPG shares many key elements with political ecology, including the three tenets referred to in my introduction, but also an epistemological "double posture" (cf. Gautier and Benjaminsen 2012, Robbins 2012). That is, it takes seriously the knowledge created by the natural sciences at the same time as deconstructing the categories and the authority of these sciences.

The third phenomenon I see as contributing to the resonance of critical physical geography might be the rise of the label "science". In my view, "critical" is a necessary antidote to "science", to question the modernist scientific separation of nature and society and the power relations in the production of knowledge. Let me explain. In the past decade or two, it has become trendy to re-label various domains of inquiry with the epithet "science". ${ }^{2}$ We now have, for instance, conservation science (Kareiva and Marvier 2012), land change science (Gutman et al. 2004), sustainability science (Kates et al. 2001), resilience science (Leslie and Kinzig 2009), vulnerability science (Cutter 2003) and, of course, invasion science (Richardson 2011b). Two contradictory trends seem to be pushing this fad. One is the use of 'science' to replace 'biology' or some other disciplinary epithet in order to represent an interdisciplinary spirit, particularly across a natural-social divide. The second trend is the recourse to 'Sciencewith-a-capital-S' to assert a sense of authority, and sometimes to draw a line between 'sciency' epistemologies (whether natural science or social science) and other interpretive or critical approaches.

The interdisciplinarity across the nature-society divide in these 'sciences' is often couched in the language of 'coupled systems'. In many cases, there is an implicit assumption that the natural sciences will set the "factual parameters", whereas the humanities and social sciences will assess impacts, develop solutions, and convince people of the issue at hand (Demeritt 2009, p. 128, Lidström et al. 2015, p.9). In invasion science in particular, the feeling that sometimes emerges is that social scientists are invited to collaborate only to help invasion 
scientists find out how to cope with attitudes, values, and perceptions among the public which conflict with the biologists' goals of managing invasive species (Lidström et al. 2015). For instance, Estévez et al. (2015)'s excellent review of socio-cultural factors in conflicts over invasions nonetheless concludes that more effective risk communication from scientists to the public will help avoid conflict (and, implicitly, allow the fight against invasives to continue). This model of knowledge creation and action--where science creates privileged knowledge that then calls on social sciences to help apply this knowledge--is the opposite of a 'critical' approach. The consequence is that certain forms of knowledge production and communication are excluded, and such coupled approaches can become apolitical, technical approaches indisposed to interrogating the social assumptions, values, and power relations that underlie them. Hence the need for a "critical" approach to counterbalance the "science" approach, not only to do science but also to interrogate unstated power relations, categories, and ideologies.

In the next four sections, I seek to do exactly this for the study of biological invasions. I begin by briefly placing the field in its context: where it comes from, and what inherited assumptions or path dependencies it gains from its particular historical roots. Then I investigate a series of debates in invasion science (including those mentioned in the introduction) that are ripe for CPG-style reflection and critique. ${ }^{3}$ For each, I demonstrate what is at stake and why it matters.

\section{Invasions: History of a Science}

The ability to take a step backwards, to gain perspective, is crucial to a critical reading of what a particular science is doing and why (see Davis, Marchesi, and Sayre, this volume). For instance, Thomas Malthus's widely known theories on population growth take on a different significance if one takes into account the fact that he developed his ideas as a politically engaged actor in the context of crowded, burgeoning 18th century London experiencing the birth pains of the industrial revolution and an associated urban proletariat. The same goes for the study of invasive species. Indeed, perhaps tellingly, in the $19^{\text {th }}$ century a dominant scientific approach to many plants and animals now considered invasive was acclimatization. Associated with colonialism and settler societies, acclimatization sought to 'improve' environments by purposefully introducing and propagating alien plants and animals: rabbits, willows, and trout in Australia, eucalypts and acacias around the Mediterranean (Osborne 2000).

The study of plants, animals, and other organisms that are 'out of place'--their characteristics, the causes of their displacement, their behavior in their new environments, their impacts on ecology and economy, people's reactions, and management strategies--not coincidentally goes back to the same historical period. Histories of invasion biology and allied fields have already been written (Davis 2009, Johnson 2010, Chew and Hamilton 2011, Richardson 2011a, Frawley and McCalman 2014, Vaz et al. 2017); here I highlight some key factors shaping the nature of the field and its assumptions.

The modern field of invasion biology dates to the 1980s. Large international research consortia served as catalysts, such as the international 'SCOPE 37'4 research program launched in 1982 (Drake et al. 1989, Simberloff 2011a, 2013, Kull and Rangan 2015). In the 1990s, the field was institutionalized into science, policy, and programs. Publications on invasions grew ten-fold; new specialized journals like Biological Invasions and Diversity and Distributions were founded under field-leading editors and SCOPE participants Daniel Simberloff and David Richardson; governments funded programs like the European Commission's project to inventory invasive species (DAISIE) or the Global Invasive Species Programme (GISP), as well as diverse national and international legislation (Vaz et al. 2017).

The invasion biology field builds on a variety of practical and intellectual heritages. Some of the categories and terminologies of invasion--which as we will see later, are highly contested--draw on ideas of European naturalists working in peri-urban countrysides in the 1800s and early 1900s, such as Hewett Watson and Albert Thellung (Chew and Hamilton 2011, Kowarik and Pyšek 2012). The field of weed science, which crystallized with the edition of a field-defining textbook in 1942 categorizing weed types as well as focusing on practical control strategies, was explicitly designated as a stepping-stone for the SCOPE program (Kull and Rangan 2015). In the post-war period, weed sciences and weed services boomed with the conversion of wartime industries into the production of fertilizer and chemical herbicides; this martial legacy shadows invasion biology to this day (Atchison and Head 2013, Tassin 2017). Finally, it is common to refer to Oxford biologist Charles Elton, who published the prescient Ecology of Invasions by Plants and Animals in 1958, as the field's father or prophet, despite the thirty-year gap between his work and the efflorescence of the field (Simberloff 2011a, Chew 2015, Vaz et al. 2017). Elton's work, publicized via BBC radio broadcasts, set a pattern of use of military metaphors in describing invasions.

The SCOPE program re-directed and applied these inherited concepts and approaches to the study of natural ecosystems and biodiversity (e.g., Drake et al. 1989, Cronk and Fuller 1995). From the 1980s, studies of invasion in natural areas took off. It was increasingly informed by the broader field of ecology's relative disengagement from anthropic landscapes. Most invasion biology work in the 1990s and 2000s, for instance, largely ignored 
cities and other strongly humanized areas, despite the irony that the objects of study were human-introduced species (Salomon Cavin and Kull 2017).

\section{Invasions: Words and Labels}

An aspect of invasion biology that has already received a lot of critical attention is the vocabulary of "alien invasive species". A lot of ink has been spilt about the war metaphors of enemy invasion, such as those used by Elton in his 1958 tome, and the term alien with its resonance in both pop culture and immigration politics. My point is not to rehash these debates (see, for instance, Peretti 1998, Comaroff and Comaroff 2001, Subramaniam 2001, Simberloff 2003, Larson 2005, Warren 2007, Davis 2009, Kull and Rangan 2015), but to point out the importance of attention to labels and language in highlighting potential underlying assumptions, potential foregone conclusions, in scientific studies. Humans are of course used to words having different meanings in different contexts (e.g., invasion as a military term vs. as a medical term); any other term one could choose would come with its own baggage (for instance colonizing or pioneer species carry their own metaphorical echoes). But a critical approach might follow the practical advice of Kueffer and Larson (2014) in evaluating metaphors in terms of factual correctness, socially acceptable language, neutrality, and transparency. It would then go further to evaluate what kinds of concrete impacts the choice of terms actually has on the conduct of science, on the framing of policy debates, and on practical management actions (Larson 2011).

Practitioners of invasion biology are highly aware of the rhetorical and ideological importance of labels. This applies even to the name of the field itself. While the field has for several decades passed under the label invasion biology (or invasion ecology), two new field names were recently proposed. The first is "species redistribution ecology", or SPRED ecology, proposed in a textbook titled Invasion Biology that bravely sought to abolish its own name (Davis 2009). Davis' proposal is based on the argument that the fundamental object of study of invasion biology--how and why species spread and move--falls within community ecology and biogeography, and does not merit a different field. ${ }^{5}$ He notes that the term invasion is too emotive, and that too much unfounded stock is put on the distinction between native and alien. The neologism SPRED ecology has, however, not taken off. ${ }^{6}$ It is, perhaps, hampered by its narrow focus, and by the fact that it was promoted by an author somewhat outside the mainstream (Davis was the author to whom 141 scientists objected in this chapter's opening paragraph).

In contrast, the successful term "invasion science" comes from a top scientist in the field, David Richardson, visionary leader of the world renowned Centre for Invasion Biology at Stellenbosch University, alumnus of the SCOPE program, long time editor of Diversity and Distributions, and editorial board member of Biological Invasions (Richardson 2011b). As noted in Section 2, the epithet "science" appears to carry a particular strategic ambit of legitimacy attached to the authority of science. In addition, the replacement of "biology" with "science" also tries to signal a broadening of the scope of the field from just biological aspects of invasions to concerns with costs and benefits and human value systems (Richardson and Ricciardi 2013). The ecumenical focus of the title 'invasion science', its links to institutional centers of power, and its shying away from thorny debates over terminology would seem to explain the label's success. Thus the contrast between the stories of the two neologisms--one stuck in the starting blocks, the other running to an early lead--merits CPG-style attention, as it demonstrates not only the importance of power and networks in the production of scientific knowledge, but also the stickiness of paradigmatic concepts.

\section{Invasions: Categories}

Defining what one is studying is crucial to any science. Yet, how this object is defined involves choices and boundaries, and these have consequences--on the science that is done, and on the ways in which it is relevant to policy and management. As Nathan Sayre has noted, scientific categories should not be taken for granted (Sayre 2015). Invasive species is the central category for the type of research this chapter engages with. But the definition of this term is far from settled. There are three ideal-type concepts that appear singly or in various combinations in most definitions of invasive species (cf. Williamson 1996 p. 58-59, Boonman-Berson et al. 2014, Kull et al. 2014, Tassin 2014).

First, some definitions emphasize origins. In this model, an invasive species is an alien, that is, a species that comes from elsewhere. This definition emphasizes the crossing of some biogeographical barrier (Richardson et al. 2000). This definition carries an unexamined ideology of natural purity and nativeness and is troubled by a black-and-white dichotomy between alien and native that in many cases is not so clear--there are quite a few species whose origins or original distributions are unclear (Bean 2007). To overcome these issues some definitions further specify that transport of the species has to be at the hand of humans (Richardson et al. 2000); if a species arrives naturally then it does not count. While practical, this potentially introduces an ideology that humans are separate from nature.

A second set of definitions emphasize behavior. In this model, an invasive species is an invader, one that gains terrain, spreads quickly, and becomes dominant in a given ecosystem (Valéry et al. 2008). On its own, this definition poses the problem of distinctions of temporal and spatial scale: what distinguishes an invader, then, from a pioneer species or a colonizer? (Hoffmann and Courchamp 2016a). 
The third set of definitions emphasize impacts. In this model, an invasive species is a weed or a pest, one that has negative impacts on native vegetation or on society, public health, or the economy (McNeely 2001, Simberloff et al. 2013). This is a value judgment, which raises the question of how this value is determined, by whom, or from what perspective. It also predisposes the field towards an investigation of only the negative impacts and not the positive (Tassin and Kull 2015).

Definitions of the invasive species concept have been hotly debated in the field (Colautti and Richardson 2009, Blackburn et al. 2011); in that sense, CPG-style work has been initiated. But definitions are often not made explicit in studies, with consequences on the types of conclusion that become possible and the implicit judgments behind them. For instance, a study based on the assumption that invasives must be alien might miss a native species that--for whatever reason (climate change, human disturbance)--currently acts as a landscape transformer. Or, an article surveying a taxa or a region to establish an inventory of invasive species might have as its criteria that a scientific study or expert opinion has called that species 'invasive' without regard to the definition used (as I did my self in a survey of introduced plants in Madagascar: Kull et al. 2012). This potentially mixes together plants from elsewhere with noxious weeds and those that spread quickly, hiding large differences in ecological processes and human interactions.

In addition to defining what invasive means, one must also consider what the implications are of selecting species as the central unit of analysis. A critical approach contributes to highlighting the advantages and disadvantages, winners and losers, or hidden assumptions behind the choice of units of analyses. In invasion studies, it has long been noted, for instance, that it is particular populations of a species, in specific contexts, which are invasive, not the species itself (Colautti and MacIsaac 2004). The Monterrey pine, or radiata, is a case in point: it is endangered in its native habitat in California, but invasive in numerous places around the southern hemisphere where it has been grown for forestry. The impression given in study after study is that it is the biological species that is invasive, not particular populations in particular contexts. This results in online lists and databases of flora and fauna that typically list invasive species abstracted from their geographic context. Regional listings are often agglomerated to larger regional or national scales (a plant exhibiting weedy behavior in Miami is listed as invasive in Florida, and thus in the United States). So in many cases one can quickly find on the internet or in scientific publications that species A is 'reported invasive in country X, Y, and Z', even though the inclusion of some of those countries might involve very minor populations. This results in lists of invasive species in online databases or legislative appendices that forbid transport, restrict cultivation, or mandate eradication with sometimes little attention to context. What appears as a precautionary principle to some might constrain legitimate choices for others.

A further consequence of the focus on species is that it distracts from the processes favoring invasion. To illustrate, take the case of a variety of often thorny American bushes--such as such as Lantana camara, Acacia farnesiana, Mimosa pigra, Leucaena leucocephala, Prosopis spp.--that are widely seen as invasive species across the sub-humid and semi-arid tropics of the eastern hemisphere. With numerous publications and reports listing these and other species, the implicit message is that it is their fault, and that they are the entities that must be controlled. Yet these species were transported (originally) by humans, and they tend to be present in environments rendered 'invasible' by human actions: by our lighting of grass or forest fires, by our grazing practices, or by our introduction of seed dispersers, like the common mynah bird. The outcome is that invasion biologists and environmental managers address invasive species more than arguably more relevant populations, human disturbances, or specific places.

An alternative to species-based approaches--an alternative that should be of particular interest to geographers-is a place-based approach. Together with Jacques Tassin, I suggested in an earlier article that:

"Instead of using an a priori judgment to call for a blanket ban of a wide array of plant species, the focus should be on the processes that societies (communities, governments, agencies) use to anticipate and debate the changes to landscapes and human lives that are possible outcomes of specific plant introductions and diffusion in specific places. Who are the winners and losers, now and in the foreseeable future? ...Who has the right to decide, and the might to enforce? .... We suggest an evidence-based, context-specific, socially-negotiated approach.... The judgment of 'weed versus useful' should not be made at a global level, it should remain contextual to local and regional scales, to particular ecosystems and landscapes, particular economies and sociopolitical situations." (Kull and Tassin 2012, pp. 2230 and 2232)

Recent work in the Australian outback shows how prioritizing "place-based" management over the speciesbased management imposed by government interpretations of invasion science could better address Aboriginal cultural issues, budgetary constraints, and on-the-ground outcomes (Bach 2015, Bach and Larson 2017). Critical work could further questions such as choice of scales and units of analyses and how they shape scientific, social, and practical outcomes. 


\section{Invasions: Social, Political, Ethical Dimensions}

Efforts to prevent, control, or eradicate particular invasions can be embroiled in a variety of conflicts. These include struggles over priorities, funding, responsibility, worldviews, ethics, and more. As with any intervention, there will be winners and losers. In a number of cases, for instance, the livelihoods of certain members of rural communities have become dependent on invasive species, whether for fodder, woodfuel, or food, to the point that the removal of the invader would have negative livelihood outcomes (Shackleton et al. 2007, Ellender et al. 2010, Kull et al. 2011, Middleton 2012). In other contexts, the invasive species is more broadly disliked for its negative impacts on livelihoods (Awanyo 2001, Mwangi and Swallow 2008). A critical invasion science engages with these conflicts and builds on them to guide research. I illustrate this with two examples: the question of toxic chemicals, and the question of labor.

First, a major conundrum in invasion science is the battling of one environmental evil (invasive species) with another (chemical poisons). How does one balance a desire to combat invasions using herbicides and pesticides with the resultant environmental pollution, and with the mortality and suffering of sentient beings (in the case of invasive animals)? According to Jacques Tassin (2017), this ethical quandary has not been adequately and openly addressed in invasion studies (cf. Orion 2015). This is all the more pressing given the entanglement of weed science with the post-war chemical industry, as noted earlier. As Paul Robbins (2007) noted in his analysis of the American lawn, the chemical industry played a far-from-neutral role in the development of the cultural ideal of a perfect green suburban lawn, creating the demand for their products. A similar role in terms of invasive species management is not far fetched--as biologist and historian Matt Chew notes, invasive species are marketing opportunities for pesticide manufacturers. ${ }^{7}$

The second example is related: the control and eradication of invasive species is difficult work, potentially involving elements such as exposure to toxic chemicals, hard physical labor, and the killing of living things. These consequences are more commonly borne by certain sectors of society than others--a laboring class characterized by relative poverty, migrant status, or indigeneity (cf. Murray 1994, Atchison and Head 2013, Head et al. 2015). In northern Australia, for instance, Aboriginal rangers submit to difficult, hot, and poisonous weed work largely following the exigencies of state agency lists and contractor funding incentives. These tasks are, according to the rangers, the most unsatisfying of their job, and the most distant from their official mandate to be doing work related to 'caring for country' (Bach 2015, Bach and Larson 2017). A similar disconnect and dissatisfaction was noticed among park rangers whose jobs over a 30 year period centered on killing goats, cats, and other feral animals in the Galápagos Islands (Hennessy 2014). Similarly, South Africa's Working for Water alien management program has been criticized for risk exposure and low pay (Lidström et al. 2015, p. 23).

The scientific literature on invasions quite often frames conflicts over the management of invasive species as "conflicts of interest" (Cullen and Delfosse 1984, Shackleton et al. 2007, Estévez et al. 2015). A critical perspective on invasion studies suggests that this literature often takes on an overly simplistic "us-and-them" framing. It tends to view conflicting interests in relatively straightforward ways: for instance, community $Y$ opposes control of species X because of cultural belief Z, or because $Y$ makes money selling the products from X. Such a framing suggests that there are relatively clearly bounded interests, implying that they might be resolved through approaches such as cost-benefit analyses (Le Maitre et al. 2002) or conflict resolution and negotiation (van Wilgen and Richardson 2012, Mukwada et al. 2016). From a critical perspective, what is missing is a more complete sense of the complex historical and current entanglements that have dialectically shaped the invasion problem in different locales. Conflicts over Prosopis in Rajastan, for instance, cannot be understood without reference to questions of land access and institutional incentives to state foresters (Robbins 2001) just as conflicts over Acacia in Portugal must grapple with rural depopulation, outmigration, the history of plantation forestry, and perceptions of wildlife danger.

Instead of taking a black-and-white approach to conflicts over invasive species, a critical approach might engage more deeply with the complicated, rough-and-tumble, unpredictable, and practical necessity to 'live with', accommodate, or coexist with invasive species. This is not only because full eradication and even partial control is often unrealistic, but also because control efforts are politically or socially untenable in some contexts (Atchison and Head 2013, Chandrasena 2014, Head et al. 2015). Rangan et al. (2014, p. 124) cite a struggling cattle and sheep rancher in Australia who is constrained by invasive species policies, and who says "I'm sick and tired of poisoning the things that want to live here, and trying to raise the things that want to die". These kinds of questions around adaptation, winners and losers, and unintended consequences are rich in critical opportunities that could push invasion scientists to pose their questions and frame their approaches differently.

\section{Towards a Critical Invasion Science}

The above discussions have hinted at some directions for a 'critical invasion science'. In this concluding section, I build on the previous sections and formulate four proposals for what a critical approach to invasion science might do, and what questions it might ask. 
(a) Questioning words and labels. The terminology used in research is powerful, as it can reflect assumptions and beliefs and thus frame research questions and interpretations of results. What are the concepts used in posing questions and guiding analysis, where do they come from, what do they show and what do they hide? A critical approach would encourage invasion scientists to ask whether the use of different labels might lead to different research questions, and whether certain labels reflect the worldview (or political stance) of a particular interest group (perhaps more socially dominant) and thus might miss alternative framings and conclusions. Specifically, for invasives: one might begin with the name 'invasion science' or the term 'invasives', as I have already done above. More specifically, one can ask how the use of terminology affects research. A study I supervised in eastern Madagascar can illustrate the need for this approach. Posing the research question as "is Grevillea banksii invasive in eastern Madagascar" required the researcher to present criteria of what it means to "be invasive" (which, as we saw above, involves consequential choices between competing definitions regarding origins, impacts, and behavior) and then data to assess whether the plant meets the selected criteria. A different question, such as "why is Grevillea banksii spreading in eastern Madagascar" would have focused the research on different processes and different data. Each word selected for a research question--invasive, spread, alien, native, neophyte, naturalized, transformer species, adventive, feral--constrains the kind of information that will be sought. The terminology can be questioned before a study is undertaken, for instance when a scientists asks whether her research question should be framed using the concept of 'invasion' as opposed to 'colonization' (Hoffmann and Courchamp 2016a). Or it can be questioned afterwards, as Larson (2011) does when he ask what the impacts are of terms and metaphors like 'invasion meltdown' used to communicate research results.

(b) Questioning scale and its impacts. A critical approach would ask how it matters that research is framed at a particular temporal, spatial, or organizational scale? Does it change the questions that are asked, the evidence that is applied, or the analytical connections that can be made? Specifically, for invasives, an important scalar consideration I mentioned above is the way in which the category of biological species has become the object of analysis and communication, rather than particular populations of particular species in particular places. One crucial project for a critical invasion science would thus be to assess invasive species databases, the institutional and sociological process of their creation, and their impacts (Kull and Rangan 2015, Lidström et al. 2015), and to evaluate the benefits and consequences of a more "place-based" approach to invasion science.

(c) Caring explicitly how the science is used, who wins, who loses. Of course scientists care about these matters, but a critical approach would be explicit about it. Specifically, for invasives: the dominant discourse of the science of invasion biology is of the urgency and importance of the issue, incessantly promoted as the 'second greatest threat' to biodiversity (Chew 2015). This leads to an under-exploration of opposing views--those of rural residents whose livelihoods are based on the abundant and robust growth of certain invaders, or of people who labor in chemical protection suits in the tropical sun to poison invasive plants, or of advocates for amphibians made sick by toxic chemicals. That is, in caring narrowly for the protection of biodiversity or certain suites of ecosystem services, the broader impacts of this science is downplayed. For instance, Courchamp et al. (2017, p. 13) state that criticisms, internal strife, and an unaware society "hinder the progress of invasion biology". Similarly, van Wilgen and Richardson (2012 p. 56) basically say that opposing voices do not matter: their proposals regarding the problem of pine invasions in South Africa "will require political commitment to policies that could be unpopular in certain sectors of society." A critical approach would interest itself more in the impact of these conclusions and in opposing views. It might, for instance, seek to co-construct research questions with different interest groups (perhaps resulting in questions like: "how would eradication of species $\mathrm{X}$ affect ecological dynamics and the provision of woodfuel in this region", or "given that local stakeholders are not keen on full eradication, what are the impacts of partial control via bio-control agents on livelihoods and novel ecosystem dynamics").

(d) Questioning the voice of expertise. By this I do not mean questioning the expertise of scientists and their research outcomes. Instead, I mean questioning the voice, or attitude, or posture whereby science has a monopoly on expertise and on translating that expertise into action. Specifically, for invasives: more attention could be paid to the embedded landscape knowledge of local people about weeds and pests (Bentley et al. 2005, Vaarzon-Morel and Edwards 2012). This could be an intellectually and practically significant shift. Intellectually, because, for instance, it might contribute to a reconsideration of the kinds of questions asked. For instance, Plantago major was known by Native Americans as 'white man's footprint', a name that usefully directs attention to the society that transported the plant and aided its spread through ecological disturbance. And yet while it may be seen as an invader, it has not displaced other species and became widely appreciated in Native American communities for its different uses (Kimmerer 2013). This is also a practically important shift, because local knowledge based on landscape experience might reveal patterns and processes not easily noticed by transient field workers. More fundamentally, the sharing of knowledge and co-produced questioning might lead to better appreciation of the social complexity inherent to ecologically dynamic situations and orient research towards solutions acceptable to all parties.

In the introductory chapter, Lave et al. suggest that a critical approach leads to the asking of new questions, or to adding layers to questions we already ask, and provide an example of a case of a soil scientist working in 
Oakland, California. This applies well to the case for a "critical invasion science". Let me illustrate with a final set of examples from a research project in which I am currently involved--the rapid expansion of potentiallyinvasive Australian Acacia plantations in Vietnam (Richardson et al. 2015, Cochard et al. 2017). An invasion biologist might start and end their study with mention of widespread commercial plantations of this species, followed by investigations of dispersal mechanisms, seed banks, soil allelopathy, and spatial spread. On top of this, a critical invasion scientist might add additional layers of inquiry:

- How do political-economic factors shape the distribution of acacia plantations and thus "propagule pressure"?

- To what extent does strong government policy favoring tree cover and economic interest in acacia plantations reduce local scientific attention to potential invasive behavior?

- How does the introduction of tree breeding, and notably hybrid strains of A. mangium crossed with $A$. auriculiformis, affect seed viability, dispersal, and invasive behavior?

- To what extent is the spread of acacia constrained by dense human land use outside plantation areas?

- For which people, and in what contexts, is spontaneous acacia spread beneficial, or harmful, or irrelevant?

- How might these peoples' concerns and experiential knowledge affect the construction of research questions regarding acacia in the landscape?

A critical "spirit" is of course already widely held by many natural and social scientists. Much scientific training promotes, somewhere along the line, attention to the construction of categories, to things that do not fit preexisting models, and to the implications of one's research. But this is far from universal, and often not explicit. Furthermore, in research at the interface of society and environment, it needs to go much further, as this Handbook's introduction suggests. Because we live in a post-natural world where social processes profoundly affect almost all landscapes and environmental processes (Urban, this volume), a critical spirit is needed to incorporate attention to these social processes, often deeply structured, from the get-go, and not treat them as add-ons to the natural science problem. A critical spirit also involves holding a mirror up to science: what are the ideologies, power relations, and social legacies that shape how we produce knowledge, and what are the effects of that knowledge on the eco-social landscapes we study and the people that live in them? This kind of critical approach could benefit from broader training, reflection, encouragement, and attention.

\section{Endnotes}

${ }^{1}$ The publications cited in this paragraph are, in order, Davis et al. (2011); Simberloff (2011); Pearce (2015); Thompson (2014) for which, interestingly, the American edition subtitle is "Why invasive species aren't all bad" but Britain it is "The story and science of invasive species"; Marris (2011); Richardson and Ricciardi (2013); and Russell and Blackburn (2017).

2 For a more in-depth discussion of the "Science" phenomenon, see my blog: https://christiankull.net/2013/11/25/is-everything-a-science/.

${ }^{3}$ Courchamp et al.'s (2016) list of 24 issues in invasion science provides more inspirations for critical enquiry. ${ }^{4}$ SCOPE is the Scientific Committee on Problems of the Environment, established by the International Council for Science in 1969 (http://www.scopenvironment.org). It has sponsored over 70 authoritative investigations of particular topics, including biological invasions (number 37).

${ }^{5}$ Interestingly, a similar assertion that biological invasions and natural colonisation were not that different recently sparked a vehement debate (Hoffmann and Courchamp 2016a, b; Wilson et al. 2016).

${ }^{6}$ However, interestingly, a workshop involving a number of invasion scientists is advertised for 2018 without using the word "invasion" (the title is "Species range extensions and local adaptation"). See

http://andina4argentina.weebly.com (accessed 7 April 2017).

${ }^{7}$ See https://milliontrees.me/2017/04/01/ecological-restorations-follow-the-money/, accessed 4 April 2017.

\section{References}

Atchison, J. and L. Head. 2013. Eradicating bodies in invasive plant management. Environment and Planning D: Society and Space 31: doi:10.1068/d17712. doi:10.1068/d17712.

Awanyo, L. 2001. Labor, ecology, and a failed agenda of market incentives: the political ecology of agrarian reforms in Ghana. Annals of the Association of American Geographers 91(1): 92-121.

Bach, T. M. (2015). "All about healthy country": Aboriginal perspectives of weed management in the Kimberley, Western Australia. PhD PhD, Monash University.

Bach, T. M. and B. M. H. Larson. 2017. Speaking about weeds: Indigenous elders' metaphors for invasive species and their management. Environmental Values: in press; http://www.whpress.co.uk/EV/papers/Bach.pdf. 
Bean, A. R. 2007. A new system for determining which plant species are indigenous in Australia. Australian Systematic Botany 20: 1-43.

Beinart, W. and L. Wotshela. 2011. Prickly Pear: The Social History of a Plant in the Eastern Cape, Wits University Press, Johannesburg.

Bennett, B. M. 2014. Model invasions and the development of national concerns over invasive introduced trees: insights from South African history. Biological Invasions 16: 499-512.

Bentley, J. W., M. Webb, S. Nina and S. Pérez. 2005. Even useful weeds are pests: ethnobotany in the Bolivian Andes. International Journal of Pest Management 51(3): 189-207.

Blackburn, T. M., P. Pyšek, S. Bacher, J. T. Carlton, R. P. Duncan, V. Jarosìk, J. R. U. Wilson and D. M. Richardson. 2011. A proposed unified framework for biological invasions. Trends in Ecology \& Evolution 26(7): 333-339. http://www.sciencedirect.com/science/article/pii/S0169534711000930

Boonman-Berson, S., E. Turnhout and J. van Tatenhove. 2014. Invasive species: The categorization of wildlife in science, policy, and wildlife management. Land Use Policy 38(0): 204-212.

http://dx.doi.org/10.1016/j.landusepol.2013.11.002.

Carruthers, J., L. Robin, J. P. Hattingh, C. A. Kull, H. Rangan and B. W. van Wilgen. 2011. A native at home and abroad: the history, politics, ethics and aesthetics of Acacia. Diversity and Distributions 17(5): 810-821. D0I: 10.1111/j.1472-4642.2011.00779.x.

Chandrasena, N. 2014. Living with weeds - a new paradigm. Indian Journal of Weed Science 46(1): 96-110.

Chew, M. K. 2015. Ecologists, environmentalists, experts, and the invasion of the 'second greatest threat'. International Review of Environmental History 1: 7-4.

Chew, M. K. and A. L. Hamilton. 2011. The rise and fall of biotic nativeness: a historical perspective. Pages in D. M. Richardson, editor 50 Years of Invasion Ecology: the Legacy of Charles Elton. Blackwell, London.

Cochard, R., D. T. Ngo, P. O. Waeber and C. A. Kull. 2017. Extent and causes of forest cover changes in Vietnam's provinces 1993-2013: a review and analysis of official data. Environmental Reviews, doi: 10.1139/er-2016-0050. doi: 10.1139/er-2016-0050.

Colautti, R. I. and H. J. MacIsaac. 2004. A neutral terminology to define 'invasive' species. Diversity and Distributions 10: 135-141.

Colautti, R. I. and D. M. Richardson. 2009. Subjectivity and flexibility in invasion terminology: too much of a good thing? Biological Invasions 11(6): 1225-1229.

Comaroff, J. and J. L. Comaroff. 2001. Naturing the nation: aliens, apocalypse and the postcolonial state. Journal of Southern African Studies 27(3): 627-651.

Courchamp, F., A. Fournier, C. Bellard, C. Bertelsmeier, E. Bonnaud, J. M. Jeschke and J. C. Russell. 2017. Invasion Biology: Specific Problems and Possible Solutions. Trends in Ecology \& Evolution 32(1): 13-22.

http://dx.doi.org/10.1016/j.tree.2016.11.001.

Cronk, Q. C. B. and J. L. Fuller. 1995. Plant Invaders: the Threat to Natural Ecosystems, Chapman \& Hall, London.

Cullen, J. M. and E. S. Delfosse (1984). Echium plantagineum: catalyst for conflict and change in Australia. Proc. VI Int. Symp. Biol. Contr. Weeds, Vancouver, Canada, Agriculture Canada.

Cutter, S. L. 2003. The vulnerability of science and the science of vulnerability. Annals of the Association of American Geographers 93(1): 1-12.

Davis, M. A. 2009. Invasion Biology, Oxford University Press, Oxford.

Davis, M. A., M. K. Chew, R. J. Hobbs, A. E. Lugo, J. J. Ewel, G. J. Vermeij, J. H. Brown, M. L. Rosenzweig, M. R. Gardener, S. P. Carroll, K. Thompson, S. T. A. Pickett, J. C. Stromberg, P. Del Tredici, K. N. Suding, J. G. Ehrenfeld, J. P. Grime, J. Mascaro and J. C. Briggs. 2011. Don't judge species on their origins. Nature 474: 153-154. 
Demeritt, D. 2009. Geography and the promise of integrative environmental research. Geoforum 40: 127-129.

Drake, J. A., H. A. Mooney, F. di Castri, R. H. Groves, F. J. Kruger, M. Rejmánek and M. Williamson, Eds. 1989. Biological Invasions: A Global Perspective. SCOPE 37. John Wiley \& Sons, Chichester.

Ellender, B. R., O. L. F. Weyl, H. Winker and A. J. Booth. 2010. Quantifying the annual fish harvest from South Africa's largest freshwater reservoir. Water SA 36(1): 45-52.

http://www.scielo.org.za/scielo.php?script=sci_arttext\&pid=S1816-79502010000100006

Estévez, R. A., C. B. Anderson, J. C. Pizarro and M. A. Burgman. 2015. Clarifying values, risk perceptions, and attitudes to resolve or avoid social conflicts in invasive species management. Conservation Biology 29(1): 19-30. 10.1111/cobi.12359.

Forsyth, T. 2003. Critical Political Ecology: the Politics of Environmental Science, Routledge, London.

Frawley, J. and I. McCalman, Eds. 2014. Rethinking Invasion Ecologies from the Environmental Humanities. Routledge, London.

Gautier, D. and T. A. Benjaminsen, Eds. 2012. Environnement, discours et pouvoir: l'approche Political ecology. Éditions Quæ, Versailles.

Green, L. 2014. Ecology, race, and the making of environmental publics: a dialogue with Silent Spring in South Africa. Resilience: A Journal of the Environmental Humanities 1(2): 20pp.

Gregory, D., R. Johnston, G. Pratt, M. Watts and S. Whatmore, Eds. 2009. The Dictionary of Human Geography. Wiley-Blackwell, London.

Gutman, G., A. C. Janetos, C. O. Justice, E. F. Moran, J. F. Mustard, R. R. Rindfuss, D. Skole, B. L. Turner, II and M. A. Cochrane, Eds. 2004. Land Change Science: Observing, Monitoring and Understanding Trajectories of Change on the Earth's Surface. Kluwer Academic Publishers, Dordrecht.

Head, L., B. M. H. Larson, R. J. Hobbs, J. Atchison, N. Gill, C. A. Kull and H. Rangan. 2015. Living with invasive plants in the Anthropocene: the importance of understanding practice and experience. Conservation and Society 13(3): 311-318. 10.4103/0972-4923.170411.

Hennessy, E. A. (2014). On the backs of tortoises: conserving evolution in the Galápagos Islands. PhD, University of North Carolina.

Hoffmann, B. D. and F. Courchamp. 2016a. Biological invasions and natural colonisations: are they that different? NeoBiota 29: 1-14. 10.3897/neobiota.29.6959.

Hoffmann, B. D. and F. Courchamp. 2016b. When similarities matter more than differences: a reply to Wilson et al. NeoBiota 31: 99-104. 10.3897/neobiota.31.10290.

Johnson, S. 2010. Bioinvaders, White Horse Press, Cambridge.

Kareiva, P. and M. Marvier. 2012. What is conservation science? BioScience 62(11): 962-969.

Kates, R. W., W. C. Clark, R. Corell, J. M. Hall, C. C. Jaeger, I. Lowe, J. J. McCarthy, H. J. Schellnhuber, B. Bolin, N. M. Dickson, S. Faucheux, G. C. Gallopin, A. Grübler, B. Huntley, J. Jäger, N. S. Jodha, R. E. Kasperson, A. Mabogunje, P. Matson, H. Mooney, B. Moore, III, T. O'Riordan and U. Svedin. 2001. Sustainability science. Science 292(5517): 641-642. http://www.sciencemag.org/content/292/5517/641.short

Kimmerer, R. W. 2013. Braiding Sweetgrass: Indigenous wisdom, scientific knowledge, and the teachings of plants, Milkweed Editions, Minneapolis.

Kowarik, I. and P. Pyšek. 2012. The first steps towards unifying concepts in invasion ecology were made one hundred years ago: revisiting the work of the Swiss botanist Albert Thellung. Diversity and Distributions 18: 1243-1252. 
Kueffer, C. and B. M. H. Larson. 2014. Responsible use of language in scientific writing and science communication. BioScience 64: 719-724. doi: 10.1093/biosci/biu084.

Kull, C. A. and H. Rangan. 2015. The political ecology of weeds: a scalar approach to landscape transformation. Pages 487-500 in R. L. Bryant, editor The International Handbook of Political Ecology. Edward Elgar, Cheltenham.

Kull, C. A. and H. Rangan. 2016. Political ecology and resilience: competing interdisciplinarities? Pages 71-87 in B. Hubert and N. Mathieu, editors. Interdisciplinarités entre Natures et Sociétés: Colloque de Cerisy. P.I.E. Peter Lang, Bruxelles.

Kull, C. A., C. M. Shackleton, P. J. Cunningham, C. Ducatillion, J.-M. Dufour-Dror, K. J. Esler, J. B. Friday, A. C. Gouveia, A. R. Griffin, E. Marchante, S. J. Midgley, A. Pauchard, H. Rangan, D. M. Richardson, T. Rinaudo, J. Tassin, L. S. Urgenson, G. P. von Maltitz, R. D. Zenni and M. J. Zylstra. 2011. Adoption, use and perception of Australian acacias around the world. Diversity and Distributions 17(5): 822-836. DOI: 10.1111/j.1472-4642.2011.00783.x.

Kull, C. A. and J. Tassin. 2012. Australian acacias: useful and (sometimes) weedy. Biological Invasions 14(11): 2229-2233.

Kull, C. A., J. Tassin and S. M. Carrière. 2014. Approaching invasive species in Madagascar. Madagascar Conservation and Development 9(2): 60-70. 10.4314/mcd.v9i2.2.

Kull, C. A., J. Tassin, S. Moreau, H. Rakoto Ramiarantsoa, C. Blanc-Pamard and S. M. Carrière. 2012. The introduced flora of Madagascar. Biological Invasions 14(4): 875-888.

Larson, B. M. H. 2005. The war of the roses: demilitarizing invasion biology. Frontiers in Ecology and Environment 3(9): 495-500.

Larson, B. M. H. 2011. Metaphors for Environmental Sustainability: Redefining our Relationship with Nature, Yale University Press, New Haven.

Lave, R., M. W. Wilson, E. S. Barron, C. Biermann, M. A. Carey, C. S. Duvall, L. Johnson, K. M. Lane, N. McClintock, D. Munroe, R. Pain, J. Proctor, B. L. Rhoads, M. M. Robertson, J. Rossi, N. F. Sayre, G. Simon, M. Tadaki and C. Van Dyke. 2014. Intervention: Critical physical geography. The Canadian Geographer / Le Géographe canadien 58(1): 1-10. 10.1111/cag.12061.

Le Maitre, D. C., B. W. Van Wilgen, C. M. Gelderblom, C. Bailey, R. A. Chapman and J. L. Nel. 2002. Invasive alien trees and water resources in South Africa: case studies of the costs and benefits of management. Forest Ecology and Management 160: 143-159.

Leslie, H. M. and A. P. Kinzig. 2009. Resilience science. Pages 55-73 in K. McLeod and H. M. Leslie, editors. Ecosystem-based management for the oceans. Island Press, Washington.

Lidström, S., S. West, T. Katzschner, M. I. Pérez-Ramos and H. Twidle. 2015. Invasive narratives and the inverse of slow violence: alien species in science and society. Environmental Humanities 7: 1-40.

Marris, E. 2011. Rambunctious Garden: Saving Nature in a Post-Wild World, Bloomsbury, New York.

McNeely, J. A., Ed. 2001. The Great Reshuffling: Human Dimensions of Invasive Alien Species. IUCN, Gland.

Middleton, K. 2012. Renarrating a biological invasion: historical memory, local communities and ecologists. Environment and History 18: 61-95.

Mukwada, G., W. Chingombe and P. Taru. 2016. Strifes of the frontier: an assessment of Acacia mearnsii related park-community conflicts in the Golden Gate Highlands National Park, South Africa. Journal of Integrative Environmental Sciences 13(1): 37-54. 10.1080/1943815X.2015.1130062.

Murray, D. L. 1994. Cultivating Crisis: the Human Cost of Pesticides in Latin America, University of Texas Press, Austin.

Mwangi, E. and B. Swallow. 2008. Prosopis juliflora invasion and rural livelihoods in the Lake Baringo Area of Kenya. Conservation and Society 6(2): 130-140. 
Neely, A. H. 2010. Blame it on the weeds: politics, poverty, and ecology in the New South Africa. Journal of Southern African Studies 36(4): 869-887. http://www.informaworld.com/10.1080/03057070.2010.527642

Orion, T. 2015. Beyond the War on Invasive Species: A Permaculture Approach to Ecosystem Restoration, Chelsea Green Publishing, White River Junction, VT.

Osborne, M. A. 2000. Acclimatizing the world: a history of the paradigmatic colonial science. Osiris 2nd series, Vol 15: 135-151.

Pearce, F. 2015. The New Wild: Why Invasive Species Will Be Nature's Salvation, Beacon Press, Boston.

Peretti, J. H. 1998. Nativism and nature: rethinking biological invasion. Environmental Values 7: 183-192.

Pooley, S. 2014. Burning Table Mountain: An Environmental History of Fire on the Cape Peninsula, Palgrave Macmillan, Basingstoke.

Rangan, H., A. Wilson and C. A. Kull. 2014. Thorny problems: Industrial pastoralism and managing 'country' in Northwest Queensland. Pages 116-134 in J. Frawley and I. McCalman, editors. Rethinking Invasion Ecologies from the Environmental Humanities. Routledge, London.

Richardson, D. M., Ed. 2011a. Fifty Years of Invasion Ecology: the Legacy of Charles Elton. Wiley-Blackwell, Oxford.

Richardson, D. M. 2011b. Invasion science: the roads travelled and the roads ahead. Pages 397-407 in D. M. Richardson, editor Fifty Years of Invasion Ecology: the Legacy of Charles Elton. Wiley-Blackwell, Oxford.

Richardson, D. M., J. J. Le Roux and J. R. U. Wilson. 2015. Australian acacias as invasive species: lessons to be learnt from regions with long planting histories. Southern Forests: a Journal of Forest Science 77(1): 31-39. $10.2989 / 20702620.2014 .999305$.

Richardson, D. M., P. Pyšek, M. Rejmánek, M. G. Barbour, F. D. Panetta and C. J. West. 2000. Naturalization and invasion of alien plants: concepts and definitions. Diversity and Distributions 6(2): 93-107.

Richardson, D. M. and A. Ricciardi. 2013. Misleading criticisms of invasion science: a field guide. Diversity and Distributions 19: 1461-1467.

Robbins, P. 2001. Tracking invasive land covers in India, or why our landscapes have never been modern. Annals of the Association of American Geographers 91(4): 637-659.

Robbins, P. 2007. Lawn People: How Grasses, Weeds, and Chemicals Make Us Who We Are, Temple University Press, Philadelphia.

Robbins, P. 2012. Political Ecology: A Critical Introduction (2nd ed), Wiley, Oxford.

Russell, J. C. and T. M. Blackburn. 2017. The Rise of Invasive Species Denialism. Trends in Ecology \& Evolution 32(1): 3-6. 10.1016/j.tree.2016.10.012.

Salomon Cavin, J. and C. A. Kull. 2017 (in press). Invasion ecology goes to town: from disdain to sympathy. Biological Invasions.

Sayre, N. F. 2015. The Coyote-Proof Pasture Experiment: How fences replaced predators and labor on US rangelands. Progress in Physical Geography 39(5): 576-593. http://ppg.sagepub.com/content/39/5/576.abstract

Shackleton, C. M., D. McGarry, S. Fourie, J. Gambiza, S. E. Shackleton and C. Fabricius. 2007. Assessing the effects of invasive alien species on rural livelihoods: case examples and a framework from South Africa. Human Ecology, (35): 113-127.

Shackleton, R. T., D. C. Le Maitre and D. M. Richardson. 2015. Stakeholder perceptions and practices regarding Prosopis (mesquite) invasions and management in South Africa. Ambio, 10.1007/s13280-014-0597-5: DOI 10.1007/s13280-13014-10597-13285. 10.1007/s13280-014-0597-5.

Simberloff, D. 2003. Confronting introduced species: a form of xenophobia? Biological Invasions 5: 179-192. 
Simberloff, D. 2011a. Charles Elton--Neither founder nor siren, but prophet. In: Richardson DM, editor. Fifty Years of Invasion Ecology. New York: Wiley; 2010. pp. 11-24. Pages 11-24 in D. M. Richardson, editor Fifty Years of Invasion Ecology: the Legacy of Charles Elton. Wiley, Oxford.

Simberloff, D. 2011b. Non-natives: 141 scientists object. Nature 475.

Simberloff, D. 2013. Invasive Species: What Everyone Needs to Know, Oxford University Press, Oxford.

Simberloff, D., J.-L. Martin, P. Genovesi, V. Maris, D. A. Wardle, J. Aronson, F. Courchamp, B. Galil, E. Garcl̀aBerthou, M. Pascal, P. Pyaek, R. Sousa, E. Tabacchi and M. Vilà. 2013. Impacts of biological invasions: what's what and the way forward. Trends in Ecology \& Evolution 28(1): 58-66.

http://linkinghub.elsevier.com/retrieve/pii/S0169534712001747

Subramaniam, B. 2001. The aliens have landed! Reflections on the rhetoric of biological invasions. Meridians: feminism, race, transnationalism 2(1): 26-40.

Tassin, J. 2014. La grande invasion: qui a peur des espèces invasives?, Odile Jacob, Paris.

Tassin, J. 2017. User de pesticides pour contrôler les espèces invasives : les facettes d'un paradoxe éthique. Revue d'Écologie (Terre et Vie) 72(4): xxx-xxx.

Tassin, J. and C. A. Kull. 2015. Facing the broader dimensions of biological invasions. Land Use Policy 42: 165-169. 10.1016/j.landusepol.2014.07.014.

Thompson, K. 2014. Where do Camels Belong?, Greystone Books, Vancouver.

Turpie, J. K., C. Marais and J. N. Blignaut. 2008. The working for water programme: Evolution of a payments for ecosystem services mechanism that addresses both poverty and ecosystem service delivery in South Africa. Ecological Economics 65(4): 788-798. http://dx.doi.org/10.1016/j.ecolecon.2007.12.024.

Vaarzon-Morel, P. and G. Edwards. 2012. Incorporating Aboriginal people's perceptions of introduced animals in resource management: insights from the feral camel project. Ecological Management and Restoration 13(1): 6571.

Valéry, L., H. Fritz, J.-C. Lefeuvre and D. Simberloff. 2008. In search of a real definition of the biological invasion phenomenon itself. Biological Invasions 10: 1345-1351.

van Wilgen, B. W., A. Khan and C. Marais. 2011. Changing perspectives on managing biological invasions: Insights from South Africa and the Working for Water Programme. Pages 377-393 in D. M. Richardson, editor Fifty Years of Invasion Ecology: the Legacy of Charles Elton. Wiley-Blackwell, Oxford.

van Wilgen, B. W. and D. M. Richardson. 2012. Three centuries of managing introduced conifers in South Africa: Benefits, impacts, changing perceptions and conflict resolution. Journal of Environmental Management 106(0): 56-68. http://dx.doi.org/10.1016/j.jenvman.2012.03.052.

Vaz, A. S., C. Kueffer, C. A. Kull, D. M. Richardson, S. Schindler, A. J. Muñoz-Pajares, J. R. Vicente, J. Martins, C. Hui, I. Kühn and J. P. Honrado. 2017. The progress of interdisciplinarity in invasion science. Ambio 10.1007/s13280017-0897-7. 10.1007/s13280-017-0897-7.

Warren, C. R. 2007. Perspectives on the 'alien' versus 'native' species debate: a critique of concepts, language and practice. Progress in Human Geography 31(4): 427-446.

Williamson, M. 1996. Biological Invasions, Chapman \& Hall, London.

Wilson, J. R. U., P. García-Díaz, P. Cassey, D. M. Richardson, P. Pyšek and T. M. Blackburn. 2016. Biological invasions and natural colonisations are different--the need for invasion science. NeoBiota 31: 87-98. $10.3897 /$ neobiota.31.9185. 